\title{
Excellence board of public housing in the Netherlands through a coherent set of values
}

\author{
Jan Veuger \\ NoorderRuimte, \\ Centre of Research and Innovation for Build Environment, \\ Hanze University of Applied Sciences Groningen, \\ Groningen, Netherlands \\ Email: j.veuger@pl.hanze.nl
}

\begin{abstract}
Housing associations make too small a contribution to society, the government has to step in too frequently because of maladministration, and the associations' executives are often unaware of the far-reaching impact of their decisions. These are the conclusions of new academic research conducted by Jan Veuger of Rotterdam School of Management, Erasmus University (RSM). In his dissertation, he asserts that in numerous cases there is no correlation between social and financial objectives. After extensive exploration of the literature and $\mathrm{PhD}$ studies the research design inspired based on the grounded theory, which has a certain bias as a result of the extensive literature study. My contribution to science is also showing patterns of board behaviour, whether or not in conjunction with societal and financial values of housing associations. This contribution complements studies on culture of housing associations (Dreimüller, 2008; Sinke, 2014) or only driver behavior (Heemskerk, 2013) or history of housing corporations (Beekers, 2012) or about the behaviour of housing associations (Koolma, 2009).
\end{abstract}

Keywords: housing associations; corporate real estate management; CREM; board-Netherlands.

Reference to this paper should be made as follows: Veuger, J. (2017) 'Excellence board of public housing in the Netherlands through a coherent set of values', Int. J. Sustainable Real Estate and Construction Economics, Vol. 1, No. 1, pp.77-88.

Biographical notes: Jan Veuger's common thread in the curriculum vitae is strategic management of (social) property in the business and social housing (1966). He completed his Master of Real Estate (MRE) in 2006 on a study on governance of social housing and consistency of quality instruments and promoted in 2014 at the RSM Erasmus University Rotterdam. He is thereby distinguished as the best student. He is the Owner/Director of Corporate (C) Real Estate Management, Professor of Public Real Estate at Hanze University of Applied Sciences Groningen.

\section{Introduction}

This qualitative research for control and measurement of housing corporations has a dual purpose. Firstly, to understand the significance of housing associations in the society. In addition, to expose patterns in how they function. The central question that ultimately 
needs to be answered is, are there contradictions in the social values that underpin housing corporations that have an impact on the way they are managed? Sub-questions are:

1 Can social objectives be so arranged that the underlying values these make transparent?

2 What is that social enterprise housing, what is its role in society and what is its social property?

3 How can values and orientation of corporations be assessed socially relevant based on the criteria?

4 How the board now controls in practice, it makes use of management models and are theories of Corporate Real Estate Management (CREM), derived from the commercial sector helpful?

5 Is there a solution for innovative control of housing associations?

6 Is it possible to get insight into control questions about social property?

\section{Methodology}

Methodical over a period of five years of literature, ten years of stakeholders, instruments and behaviour and a hundred years of housing corporation history, the developments in the field of value thinking and the governance of housing corporations have been studied. This qualitative study with a positivistic approach of values and governance of housing corporations has answered the research question "What social values underlie social housing and are there contradictions that affect the control of a social housing corporation?" The grounded theory (Glaser and Strauss, 1967) is the research method chosen, because that method emphasises the generating of theory-based data. Because it is flexible (Bryant, 2009; Glaser, 1992), it enables us to highlight questions that have not been asked before. These questions have been evaluated by the process (Goulding, 1999, 2002) within which the theory of this study has been constructed [Eisenhardt and Graebner, (2007), p.30].

\section{Process of this study}

This research is based upon the grounded theory which follows an inductive method for the development of that theory. This process of gathering data about thinking in values and control begins with open coding - a combination of the concepts of values, control and corporations - from data in the literature in the field of opinion and scientific research over the period 2005-2009. The found fragments are then reduced to a number of concepts such as those examined in the relevant chapters. After the extensive 
exploration of the professional literature and (promotion) research a period from 2005 to 2009 , the research design is based on the grounded theory, which does have a certain bias as a result of the extensive literature study. In line with the grounded theory, conversations with directors are entered into more or less uninhibited according to the narrative method. Afterwards, these interviews, independent of the researcher, have been thematically tagged and are submitted through a simple Delphi method - in line with grounded theory - to an expert group, creating a timeline. The results of this single Delphi method are submitted to a peer group of directors. Afterwards, these conclusions have been presented in a survey to 60 selected directors, and conclusions have been made on the basis thereof. In essence, more of a triangulation of research has taken place rather than merely interviews, Delphi method and survey. Hypotheses are omitted due to the difficulty of fitting them within the chosen research design inspired by the grounded theory. In a scheme of chapters of this study and the assessment methods used, this appears as follows.

Table 1 The research divided into chapters, stakeholders and methodologies

\begin{tabular}{|c|c|c|c|}
\hline \multicolumn{2}{|c|}{ Chapter } & \multirow{2}{*}{\begin{tabular}{l}
\multicolumn{1}{c}{ Stakeholders } \\
Directors of three corporations, \\
Woonbond and Waarborgfonds \\
Sociale Woningbouw
\end{tabular}} & \multirow{2}{*}{\begin{tabular}{l}
\multicolumn{1}{c}{ Methodology } \\
Literature review and \\
interviews according to \\
narrative method.
\end{tabular}} \\
\hline 1 & $\begin{array}{l}\text { In the eye of the } \\
\text { hurricane }\end{array}$ & & \\
\hline 2 & $\begin{array}{l}\text { Public housing: past } \\
\text { and present }\end{array}$ & - & Literature review. \\
\hline 3 & $\begin{array}{l}\text { Social enterprise } \\
\text { and real estate }\end{array}$ & - & Literature review. \\
\hline 4 & Methodology & - & Qualitative research. \\
\hline 5 & $\begin{array}{l}\text { Values and } \\
\text { experience }\end{array}$ & 451 corporation directors. & $\begin{array}{l}\text { Survey on the basis of } \\
\text { Meck's (2009) theory. }\end{array}$ \\
\hline 6 & $\begin{array}{l}\text { Management of } \\
\text { financial and social } \\
\text { values }\end{array}$ & Interest holders & $\begin{array}{l}\text { Literature review and data } \\
\text { collection. }\end{array}$ \\
\hline 7 & $\begin{array}{l}\text { Control and } \\
\text { management models }\end{array}$ & - & Literature review \\
\hline 8 & $\begin{array}{l}\text { Empirical research: } \\
\text { management } \\
\text { questions }\end{array}$ & All corporations in the Netherlands. & Confrontation matrix. \\
\hline 8.3 & $\begin{array}{l}\text { Simple Delphi } \\
\text { method }\end{array}$ & $\begin{array}{l}\text { Directors of three corporations, } \\
\text { Woonbond and Waarborgfonds } \\
\text { Sociale Woningbouw. }\end{array}$ & Narrative interviews. \\
\hline 8.3 & $\begin{array}{l}\text { Simple Delphi } \\
\text { method }\end{array}$ & $\begin{array}{l}\text { Independent chairperson Delphi } \\
\text { session. }\end{array}$ & $\begin{array}{l}\text { Thematic labelling } \\
\text { narrative interviews. }\end{array}$ \\
\hline 8.3 & $\begin{array}{l}\text { Simple Delphi } \\
\text { method }\end{array}$ & $\begin{array}{l}\text { Session with ten experts and } \\
\text { independent chairperson. }\end{array}$ & $\begin{array}{l}\text { Simple Delphi session } \\
\text { with verbal report. }\end{array}$ \\
\hline 8.4 & $\begin{array}{l}\text { Four hypotheses } \\
\text { from Delphi and } \\
\text { theory }\end{array}$ & $\begin{array}{l}\text { Directors of three other } \\
\text { corporations, one member of the } \\
\text { Supervisory Board and two heads of } \\
\text { strategy. }\end{array}$ & $\begin{array}{l}\text { Four hypotheses reviewed } \\
\text { from a single Delphi } \\
\text { session. }\end{array}$ \\
\hline
\end{tabular}


Table 1 The research divided into chapters, stakeholders and methodologies (continued)

\begin{tabular}{llll}
\hline \multicolumn{1}{c}{ Chapter } & \multicolumn{1}{c}{ Stakeholders } & \multicolumn{1}{c}{ Methodology } \\
\hline 8.5 & $\begin{array}{l}\text { Survey, validation } \\
\text { and manager results }\end{array}$ & 60 selected corporation directors. & $\begin{array}{l}\text { Validation of research } \\
\text { results by means of } \\
\text { survey. } \\
\text { Reflection of research. }\end{array}$ \\
9 & $\begin{array}{l}\text { Manage in } \\
\text { conjunction with } \\
\text { social values }\end{array}$ & - & - \\
10 & Follow-up research & - & - \\
\hline
\end{tabular}

The final result of this study is a description of missing control and supervisory issues, which is built around the accumulated and saturated core concepts that explain certain events. Through this methodology insight is obtained into patterns and processes. This makes clear how a group of people through their social interactions, define their reality and acting. It is not the guiding theory, but the practice to which research is conducted. The choice of this theoretical research was made because the research question requires insight into missing command and control questions. The answer need not be found in the existing practice or theory, but is in not asked questions that may provide a solution in the area as Einstein describes this as "The real problems cannot be solved at the same level of thinking, in which we were when we created them". The power of the grounded theory is that it is detailed in the descriptions of the method of data analysis and provides an anchoring capability and accountability of the research design. Sets the difficulty of validation and generalisation can be parried. Later on the research is done and additional literature research findings will be confronted with the insights from the theory. By this method of constant reflection additional insights flow into the analysis; the dialogue between theory and practice and enhances the consistency of the description of this research with the aim to understand. The process of this research is carried out from step to step, wherein in each step validity is ensured. The different phases, with underlying steps of this study are inspired by Pandit (1996).

\section{Planning as a possible solution}

The explanatory notes to the Housing Act 1901 (papers from 1899 to 1900, p.74, pp.8-9) shows the convincement by the government to arrive at legal measures for public housing. Especially in the social policy is assigned a prominent place for the housing problem at that time by all parties (Gerrichhauzen, 1990). The recognised importance of public health, morals and material living standards are closely related to public housing. The government at that time also comes to the economic position that can provide the Netherlands with social and manageable security. The government signalled then that they would not be able to provide any decent housing, but they could contribute in various ways to improve the conditions. The government recognised that while the state of the circumstances then were mainly in five areas: the ability to rent houses continuously harmful to health; the slight affection for improvement of housing; the construction of fragile homes that do not meet basic requirements; inadequate (good) construction and insufficient financial wealth where many were forced to take the bad with pleasure. National Treasury is also recognised as important for the nation's public 
housing interests. The government has also indicated its vision and role they should have in the task that they have to set the objectives. In the explanatory notes to the Housing Act 1901 (Papers from 1899 to 1900, p.74, p.10) is this described extensively. In 1956, leading up to the draft of the new Housing Act, the public opinion requested by the Commission Banning (Koolma 2009). It is recognised that the human being is an individual, and operates within a social environment and that the corporation is also responsible for the social needs of others. There is also drawn a parallel with the four phase model of Hardjono (1995). It can be assumed that private initiative can be regulated by the government by establishing frameworks and preconditions. This connects to the value model of public housing in the four phase model. The anchoring of private initiative can take place by allowing organisations in this field that not only operate in the interests of public housing. Private construction and rental of housing, under normal circumstances, are not subsidised. Facilitating private housing for own use, in the form of wealth creation, is partly housing interest.

Figure 1 Planning social housing (see online version for colours)

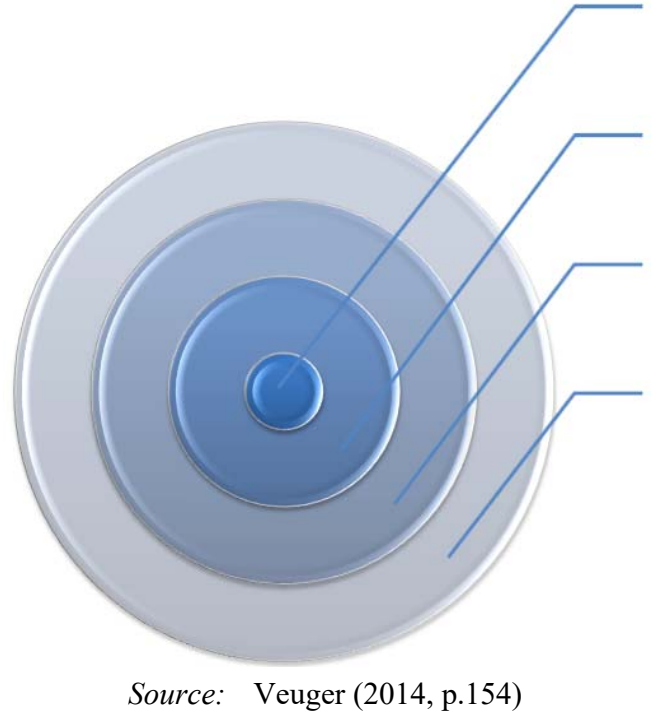

The stones: equipment capability and flexibility social property.

The corporation: return value, legitimacy and geographical scope.

The task: locking performance, socially conscious entrepreneurship, understood and broad orientation.

Pneuma: solidarity, guarantee structure, resilience and social housing policy.

The stones are value driver is the material assets consist of the possession of social property and motivators like recognition and acceptance. Flexibility of the stones is in the manufacturability which is flexible and will remain.

The organisation corporation is a value driver in the first instance by its geographic position and scope. The values assigned to a corporation on the basis of the capitalised results, its return value. Capitalised results are the proceeds of a given period to the value of the money that is involved.

The task is about the performance of the corporations are secured, with conscious social entrepreneurship is an important value driver. Being able to hear what the surroundings are with a broad spectrum of interests.

Pneuma is leading in the principle of solidarity as enshrined in the constitution. Assurance that the housing is good or works within a structure is a float value which they 
can stand up for themselves (resilience). Another value driver is the independent social housing policy that is about affordability, quality, and increase availability.

\section{Power en money are leading}

So in this thesis (Veuger, 2014) values have been studied in relation to social real estate. The social real estate [Veuger, (2014), pp.149-156] as an object constitutes material value. This material value is necessary for the commercial capital of the corporation, which uses it to administrate the social real estate and to form the organic value. The social real estate has become a precondition for the functioning of the corporation, the social value. Remarkable in the relation between social real estate and the corporation is that they can exist independently from each other, but the corporation cannot function without social real estate. Social real estate retains its values without the corporation, but not the other way around. By implementing all this, an intellectual value originates in its entirety (Hardjono, 1995). Corporations create social value by consciously allocating means for social objectives and they want to keep, innovate and repair them [Veuger, (2014), pp.57-58]. However, the corporation governor appears to stick to his own acquired capital(s) and does not allow himself to be influenced much [Veuger, (2014), pp.188-189]. When observing the capital behaviour within the organisation we notice that the investment behaviour within the corporation generally conforms to the personal behaviour of the governor [Veuger, (2014), pp.188-189]. Performance indicators such as power and money, whereby the governors do not allow themselves to be influenced by the present financial crisis, are leading in this [Veuger, (2014) pp.93-99].

\section{Responsibility of the state and of local councils}

A new organisation infrastructure is not the issue here, but especially a better effectiveness, efficiency and financial position, fed by the pneuma - working in the spirit of - to realise the mission of the corporation. Its implementation and the rationale of the corporation can be found in a more offensive cooperation, by new forms of mutual solidarity and by governing on the added values of the corporation. In the improving of the governance of the mutual solidarity three subdomains can be distinguished:

1 the housing of the primary target group

2 investing in the living and dwelling area

3 contributing to the socio-economic development of neighbourhoods (Meijerink, 2008).

The corporation also has three balanced values:

1 the fixed value (continuity)

2 the directive value (initiator)

3 the potential value (the mutual influence of neighbourhood quality and real estate value translated into social and financial value [Veuger, (2014), pp.56-58]. 
Therefore the financial position, the effectiveness and efficiency are important in the mission definition. The goal then is not the maximisation of the financial value but the maintaining of an acceptable minimum of the capital. A more conscious governance on social profitability has become a basic condition for efficient and effective practice. The effectiveness of housing corporations can primarily be considered a responsibility of the State and of local councils (Van der Schaar, 2007, 2008; Gruis, 2008).

Table 2 Lessons learn from CREM

\begin{tabular}{|c|c|}
\hline & 13 lessons \\
\hline 1 & Real estate can contribute to improving an organisation's social objectives. \\
\hline 2 & $\begin{array}{l}\text { A company-specific approach to creating value from real estate management makes a } \\
\text { greater contribution to the company's objective. }\end{array}$ \\
\hline 3 & $\begin{array}{l}\text { Making the added value measurable is essential for the role as a real estate discussion } \\
\text { partner in a company in which strategic decisions are made. }\end{array}$ \\
\hline 4 & $\begin{array}{l}\text { Becoming more flexible in the static nature of real estate and the speed at which society } \\
\text { develops can be addressed by consciously thinking about the longer term. Decisions need } \\
\text { to be taken in this regard that create opportunities for future optimisation. }\end{array}$ \\
\hline 5 & Real estate interventions and effects reinforce the organisation's objective. \\
\hline 6 & One of CREM's jobs is to formulate and implement an optimum solution. \\
\hline 7 & $\begin{array}{l}\text { CREM is playing an important role in reducing the burden of debt and building a } \\
\text { dominant market position. }\end{array}$ \\
\hline 8 & $\begin{array}{l}\text { Sustainable competitive advantage compared to other companies is determined by three } \\
\text { generic strategies that do not always go together: focus, differentiation and low cost. }\end{array}$ \\
\hline 9 & $\begin{array}{l}\text { Effects follow different eventualities and depend on the organisation's starting position } \\
\text { and culture. }\end{array}$ \\
\hline 10 & $\begin{array}{l}\text { Cause-effect chains are unclear due to influences by several factors and performances are } \\
\text { formed by complex end-means chains. }\end{array}$ \\
\hline 11 & $\begin{array}{l}\text { Real estate interventions depend on starting position and policy choices, in which context } \\
\text { is subject to change. }\end{array}$ \\
\hline 12 & A target-focussed company provides more consistent reasons for real estate interventions. \\
\hline 13 & $\begin{array}{l}\text { Collaboration is necessary in order to achieve social results, in which one monopolistic } \\
\text { arrangement cannot deliver the benefit of values. Politics also has its own dynamics and } \\
\text { interests that can cause rational considerations to disappear into thin air. }\end{array}$ \\
\hline
\end{tabular}

Source: Veuger (2014, p.132)

\section{Lessons learn from CREM}

The board of the corporation should be organised in such a way that it is possible to survey the policy, to have focus and to govern on the objectives of the corporation by incorporating the lessons of CREM [Veuger, (2014), pp.126-132]. Contrary to criticism on corporations they do professionalise, but the question is if they keep sufficient focus on the professionalisation being up to date. Otherwise chaos ensues. Why should we worry about all the instruments for comparisons and why cannot corporation governors quickly arrange this among themselves? The answer to this can be found in three reasons: 
1 lack of quality and reliability of the information streams

2 the non-guiding authorities and a perfect market mechanism

3 the behaviour of the corporation which is not up to standards (Veuger, 2014).

It is noteworthy that an explicit evaluation of the realisation of objectives, related to previous objectives, is seldom measured. It could be supposed that we are not dealing with rationally governed institutions, but rather with a controlled chaos. However, by CREM the real estate portfolio can be brought into line with the requirements of the core business of the corporation (Nourse and Roulac, 1993; O'Mara, 1999). This core business is not new. With this an optimisation of the added values of the result ensues (Maas, 2009). A real estate strategy based on values enables the corporation to engage in a competitive (Porter, 2004a, 2004b; Singer et al., 2007), but also a moral strategy (Krumm, 1999, 2001; Lindholm, 2008). Lessons learn from CREM are listed in Table 2.

\section{The state as a counterbalance}

The multidisciplinary character of social real estate management can be a bottleneck with the determining of observations that are important if they are not recognised and acknowledged. If an assignment and its measurability are not defined and organised, governability and taking officials to task over this will have no effect whatsoever. The time dimension influences value definitions from a historical context. Changes of value definitions affect the valuing and the thinking in it. Besides valuing depends on the person who defines and values quality of living environment. Real estate is a social reality with varying meanings for the people around it. It is a way of financing and valuing in the sense of usefulness. The orientation on change influences the innovativeness and flexibility of the corporation and various values. Orientation on change must be seen as proof that the corporation is capable of genuine innovation of the accumulated capital and of consolidating and increasing it. If it is capable of this it will lead to a richer corporation that will unite everyone with new developments and ideas. The future leadership of a corporation in the corporative world is not determined by its financial means, but by its ability to use those means for a particular purpose. But what would the consequence be if the monopoly position of the corporation sector were rescinded? Ethics is about values and value systems within a united company. Rank, position and power are important criteria and generally more important than money. But of course money is the medium to express rank, position and power. The financial, and therefore also the real estate market, is a market that exaggerates by irrational behaviour. Fear to 'eat or be eaten' determines the mechanism of people. Financial, and therefore real estate markets are always unstable and always have to be regulated. The corporation should especially have a serving and not a dominant role. We all have different world views, and that is why regulation is important. Anchor points for this are: own capital, being transaction-driven and regulation of large players, in which the state should be a counterbalance.

The partial conclusions of this study (Veuger, 2014) are: 
1 Improving the social objectives of the governance of corporations must be reflected in three sub-areas:

a the housing of the primary target

b investing in the living and living environment

c contribute to the socio-economic development of neighbourhoods.

In addition, its financial position, effectiveness and efficiency are important for improving the social objectives of the governance of corporations [Veuger, (2014), pp.56-59].

2 Existing legal forms in themselves for the corporation do not truly prevent. Giving her The specific characteristic of the social property relates to

a a building-related communication

b facilitating a need

c provide for the needs of others from a certain recognised public interest [Veuger, (2014), pp.99-100].

3 Corporations are focused on creating social values by consciously allocating resources for social objectives and wanting to preserve these values, restoring and renewing. Social integration and organisation of the sector are important in determining which behaviours determine [Veuger, (2014), pp.99-100].

4 The board controls in practice with control models, but not in coherence between financial and social returns, social trust, effectiveness and efficiency. CREM as a theory may play a role in the coordination of values [Veuger, (2014), pp.132-135].

5 Stories and performance are not connected with each other by the board. A possible solution for real innovation in the fourth age of housing associations is planning in conjunction with social values [Veuger, (2014), pp.161-164].

6 The multidisciplinary nature of social property management is not a problem as definitions and observations are clear. Not mutually hard and soft skills do form a bottleneck in the overall control of a corporation and its accountability

[Veuger, (2014), pp.187-189].

\section{Overall summary conclusions}

What would it take us as the monopoly position of the corporation sector is lifted? We know that we are now paying more, but corporations are also competent in their task. By taking more from the system also creates a more objective perception. Ethics is about values and value systems within an enterprise. But that does not mean we have direct full ethical behaviour. Rank, position and power are important criteria and generally more important than money. Money is the medium rank, position and power to give. The financial and thus the real estate market is a market that exaggerates by irrational behaviour. Financial and real estate markets are always so unstable and they should always be regulated. The corporation should focus a serving and no dominant role. The low proportion of the capital makes the system work in the market. We all have a different view on the world, and therefore regulation of interest is needed. Anchor points 
therefore are own capital, control of transaction and regulation of big players, for which the State must form a counterbalance. The last summary conclusion can be drawn from previous sections of this chapter to answer the central question. The overall summary conclusion to answer the central question: "are there contradictions in the underlying social values from housing corporations that affect the way they are governed?" is:

Directors, at the highest level thinking about how to deal with values ensure they drive on their own, monitor, know the consequences and take responsibility.

The research question has led to five propositions and its conclusions form the basis further in the three follow-up propositions. These three follow-up propositions deserve further attention for closer research into governability of corporations: the housing cooperative as a lever, the possible incorporation of CREM within a corporation and autopoiesis of corporation governors. The follow-up propositions are:

a a cooperative form - embodied by the Seven Cooperative Principles (1844) - causes a collection of values in socio-economic developments

b a non-monopolistic position generates the future value of a corporation

c as long as autopoiesis of corporation governors exists this results in governance unchangeability.

The community would be leader of the objective of public housing if we control the inner resistance of desire and power. Only this quest for excellence will not appear as an inorganic value, but focus on the pneuma of public housing through a coherent set of social values can advance public housing.

This science, built on facts, is like a house that is built of stones. And not like an accumulation of facts, like a heap of stones in the form of a house.

\section{Scientific contribution}

The scientific contribution in respect of the theory of value conflicts is the following. The multidisciplinary nature of social property management is not a problem as definitions and observations are clear. Interrelated hard and soft skills do not constitute a bottleneck in the overall control of a corporation and its accountability. If a task and the measurability of it not defined and organised, controllability and addressing this has no effect. The dimension of time affects value concepts from a historical context. Changes affect the valuation of value concepts and thinking it. In addition, valuation depends on the person who defines quality of life and love. Real estate is a social factor with varying meanings for people around them. She is giving a method of financing and value in terms of utility. The orientation change affects the innovativeness and flexibility of the corporation and to different values. Orientation change should be seen as evidence that the corporation is capable of true renewal of the accumulated assets, consolidate it and multiply. If they can do that, that will lead to a richer corporation where everyone can put behind new developments and ideas. The future leadership of a corporation in the corporation world is not determined by the possession of resources, but it can focus those resources on a particular goal. In ethics is about values and value systems within an enterprise. Rank, position and power are important criteria and generally more important than money. Money is the medium rank, position and power to give. The financial and thus the real estate market is a market that exaggerates by irrational behaviour. Financial 
and real estate markets are always so unstable and must be regulated. The corporation should focus a serving and no dominant role. Regulation is thereby trying to bring different images of reality together. Anchor points for this are: equity, transaction control and regulation of big players, for which the state should become a counterbalance. My contribution include studies on culture of housing associations (Dreimüller, 2008) or only driver behaviour (Heemskerk, 2013) or history of housing corporations (Beekers, 2012) or only strategic (Nieboer, 2009) or social inequality and segregation (Van Eijk, 2010) or about the behaviour of housing associations (Koolma, 2009) to.

\section{References}

Beekers, W. (2012) Het bewoonbare land. Geschiedenis van de volkshuisvestingsbeweging in Nederland, Thesis, Boom, Amsterdam.

Bryant, A. (2009) 'Grounded theory and pragmatism: the curious case of Anselm Strauss' [online] http://www.qualitative-research.net/index.php/fqs/article/viewArticle/1358/2850.

Dreimüller, A.P. (2008) Veranderen is voor anderen, Thesis, Erasmus University Rotterdam, Rotterdam.

Eisenhardt, K.M. and Graebner, M.E. (2007) 'Theory building from cases: opportunities and challenges', in Academy of Management Journal, Vol. 50, No. 1, pp.25-32.

Gerrichhauzen, L.G. (1990) Het woningcorporatiebestel in beweging, Thesis, Univeristaire Pers, Delft.

Glaser, B.G. (1992) Basics of Grounded Theory Analysis, Sociology Press, Mill Valley, CA.

Glaser, B.G. and Strauss, A.L. (1967) The Discovery of Grounded Theory: Strategies for Qualitative Research, Alkine Transaction, London.

Goulding, C. (1999) Grounded Theory: Some Reflections on Paradigm, Procedures and Misconceptions, Working paper, University of Wolverhampton, Wolverhamton.

Goulding, C. (2002) Grounded Theory, Sage, London.

Gruis, V.H. (2008) 'BBSH is prima basis voor corporatiebestel nieuwe stijl', Tijdschrift voor de volkshuisvesting, Vol. 14, No. 6, pp.50-53.

Hardjono, T.W. (1995) Ritmiek en organisatiedynamiek: vierfasenmodel met aangrijpingspunten voor organisatorische interventies ter vergroting van de effectiviteit, efficiency, flexibiliteit en creativiteit, Thesis, University Eindhoven, Kluwer, Deventer.

Heemskerk, M. (2013) Bestuursgeheimen. Over samenhang tussen leiderschapsrollen van bestuurders, strategische profielen en prestaties van woningcorporaties, Thesis, Eburon, Rotterdam.

Koolma, H.M. (2009) Verhalen en prestaties: een onderzoek naar het gedrag van woningcorporaties, Thesis, Erasmus University Rotterdam, Rotterdam.

Krumm, P.J.M.M. (1999) Corporate Real Estate Management in Multinational Corporations, Thesis, University of Delft, Delft, Arko, Nieuwegein.

Krumm, P.J.M.M. (2001) 'History of real estate management from a corporate perspective', Facilities, Vol. 19, No. 7, pp.276-286.

Lindholm, A.L. (2008) Identifying and Measuring the Success of Corporate Real Estate Management, Thesis, Helsinki, Finland.

Maas, K. (2009) Corporate Social Performance: from Output Measurement to Impact Measurement, Thesis, Erasmus University Rotterdam, Rotterdam.

Meck, S. (2009) Vorschläge für Projekte im Forschungsgebiet 'Value Investing' oder das wertorientierten Investment, Lehrstuhl für Finanzpsychologie und -soziologie, Berlin.

Meijerink, R. (2008) Nieuw Arrangement overheid-woningcorporaties, Ministerie WWI, Den Haag; Aedes, Hilversum. 
Nieboer, N. (2009) Het lange koord tussen portefeuillebeleid en investeringen van woningcorporaties, Thesis, University of Delft, Delft.

Nourse, H.O. and Roulac, S.E. (1993) 'Linking real estate decisions to corporate strategy', in Journal of Real Estate Research, Vol. 8, No. 4, pp.475-494.

O’Mara, M.A. (1999) Strategy and Place: Managing Corporate Real Estate and Facilities for Competitive Advantage, p.349, Free Press, New York.

Pandit, N.R. (1996) 'The creation of theory: a recent application of the grounded theory method', The Qualitative Report, Vol. 2, No. 4.

Porter, M.E. (2004a) Competitive Advantage: Creating en Sustaining Superior Performance, p.557, Free Press, New York.

Porter, M.E. (2004b) Competitive Strategy: Techniques for Analyzing Industries and Competitors, p.396, Free Press, New York.

Singer, B.P., Bossink, B.A.G. and van de Putte, H.J.M. (2007) 'Corporate real estate and competitive strategy', Journal of Corporate Real Estate, Vol. 9, No. 1, pp.25-38.

Van der Schaar, J. (2007) 'De toekomst van de woningcorporaties', Real Estate Magazine, No. 50, pp.30-34.

Van der Schaar, J. (2008) 'Woningcorporaties in ontwikkeling', De ontwikkeling van woningcorporaties, $\mathrm{KWH}$, Rotterdam.

Van Eijk, G. (2010) Unequal Networks: Spatial Segregation, Relationships and Inequality in the City, Thesis, University of Delft, Delft.

Veuger, J. (2014) Materieel Immaterieel. Besturing van woningcorporaties in samenhang met maatschappelijke waarden, Thesis, RSM Erasmus University Rotterdam, Rotterdam. 